\title{
John Donne's Poetics of Mediation
}

\section{DIANNE MITCHELL}

\begin{abstract}
Some of Donne's earliest works are his verse letters to male friends, poems noted for their remarkable expressions of same-sex desire. This essay proposes that these erotics are, in fact, nearly always mediated by a series of poetic proxies, figures which include female bodies and metrical malfunctions, among others. This essay unfolds what it calls Donne's "poetics of mediation" by offering a close analysis of several of Donne's homosocial verse letters as well as the less familiar contributions of his friends. It ultimately suggests, however, that Donne's queer formal strategy is deeply bound up with the material conditions of his poetic production and transmission. Considering the practicalities of the postal system by which Donne and his friends communicated from afar helps expose how these verse letters both reinscribe and disguise their reliance on real intermediaries.
\end{abstract}

Early in its four-hundred-year history, the Westmoreland Manuscript, a collection of John Donne's poems in the hand of his former Lincoln's Inn companion Rowland Woodward, was censored. ${ }^{1}$ An owner or reader took pen and ink and scribbled out passages in three of the numerous verse letters Donne had written to male friends as a law student during the early 1590s. All three censored poems are addressed to the same reader: "T.W." or Thomas Woodward, younger brother of the copyist and, at the time of his receipt of Donne's verse, an adolescent studying at Cambridge University.

The most aggressively edited of Donne's verse letters headed “To Mr T.W." is a sonnet in seven couplets opening with the injunction "Hast thee harsh Verse." Here is how the poem appears in the censored manuscript, now housed in the Berg Collection at the New York Public Library:

To Mr T.W.

Hast thee harsh Verse as fast as thy lame measure will give thee leave, him my payne $\&$ pleasure. 
I have given thee, \& yet thou art to weake

feete, \& a reasoning Soule \& tong to speake.

Plead for me, and so by thyne \& my labor,

I ame thy Creator, thou my Savior.

Tell him all questions which Men have defended

Both of the place \& paynes of hell are ended.

And tis decreed that hell is but privation

Of him, at least in this Earth's habitation.

And tis wher I ame, wher in every streete

Infections follow, overtake and meete.

Live I, or dy by you my Love is sent

And you are my [pawnes] or els my Testament $(1-14){ }^{2}$

Why has Donne's epistolary sonnet been rendered a maimed eight-and-a-half lines? Two and a half decades ago, George Klawitter saw in this damaged copy a Renaissance reader's recognition of something modern scholarship had largely chosen to ignore: the presence of same-sex desire in the writings of a man known to history as a "great frequenter of ladies" (ix). According to Klawitter, the censor's hatchet-job represents a homophobic response to Donne's heady claims that a male youth might be his "payne \& pleasure" (line 2), or that damnation, far from being "the everlasting absence of God" (as Donne would later assert in a sermon preached to the Earl of Carlisle), was instead the absence of Thomas Woodward (12; Saunders 67). Distaste for blasphemy, Klawitter concedes, may explain why Donne's bold comparison of himself and his letter to "Creator" and "Savior" was crossed out (11). In fact, this theologically risqué couplet was routinely omitted from contemporary manuscript copies and even early printings. Taken as a whole, however, "Hast thee" is read as a site of transgressive homoerotic longings whose excised lines are precisely those judged too 
"compromising"-too intense, that is, in their expression of male-male love (a quality expressly associated with the sodomitical)-for at least one member of Donne's audience (214n; Stevens 136).

Klawitter's book remains an important intervention, particularly in its reluctance to naturalize or downplay the acuteness with which Donne depicts the condition of T.W.'s absence. Yet, this essay, which also concerns Donne's earliest verse letters to T.W. and other young men, does not emulate Klawitter's aim of “outing” Donne as part of the interpretive process. I will, however, argue that "Hast thee harsh Verse," the "smoking gun" of Klawitter's thesis, is a deeply queer poem. Here, I borrow from Laurie Shannon's compelling definition of “queer,” which draws on the word's possible etymological origins in the German quer ("transverse, oblique, crosswise," etc.) to describe that which "stands (or moves) at an angle to something else" (Lear's 176). For Shannon, Nature's much remarked-on errancy in Shakespeare's King Lear is evidence of the inherent queerness of Lear's "Cosmos" $(176,171)$. Applying to lyric poetry this notion of queerness as a swerve from the "ordinary course" (176), I contend that the currents of same-sex desire circulating between Donne and his male addressees are hardly as direct as Klawitter would have them, or as the poems' apparent censorship might imply. For if the poetic situation of one man professing his love for another strikes us as queer in the most familiar sense, just as queer, I propose, are Donne's verse letters' routine re-routings of this love through a baffling series of formal proxies that include apostrophic addressees, deficient prosody, and fertile female wombs.

The first part of this essay traces what I call a "poetics of mediation" across a number of Donne's early poems to men associated with Cambridge University and the Inns of Court, as well as across poetic responses he received from these men in turn. Without downplaying the homosocial erotics of these exchanges, which I read within the stunningly capacious context of early modern same-sex friendship (Tosh 7), I describe the queerness of the poems in terms of the indirections by which these erotics are expressed. ${ }^{3}$ The second half of this essay proposes two possible (and 
interconnected) sources for this queer formal strategy. It does so by exploring an aspect of these verse letters rarely integrated into their literary analysis: the material conditions of their earliest transmission. ${ }^{4}$ Donne's poetics of mediation, I will suggest, was a natural response to a real problem of geographical separation, one which made the epistolary situation of the poems more than just a pretense. Yet, I argue, too, that from the circumstances of these verse letters' exchange emerges a strange form of censorship, one no less significant than that now etched across the surface of Donne's poems to T.W. in the Westmoreland Manuscript. For even as Donne and his friends redirect homosocial desires through figures such as flawed meter or a female Muse, they efface the historical presence of yet another mediator-one whose routine participation in these exchanges, I will show, was essential to their success. The significance of this marginalized intermediary comes into view only when we turn from Donne's letters in verse to his surviving letters in prose.

\section{I.}

"By you my Love is sent" (line 13), Donne writes near the end of "Hast thee harsh Verse." Whom does he address with such conviction? A conventional method for launching classroom discussions of lyric, the question of who, in a poem, is purportedly being "spoken to" can help us begin to explore how male-male love is mediated or rendered less "straight" in Donne's verse letters than it might initially appear. For, simplistic though it may be, it is worth observing that "Hast thee" is not addressed to a young man at all. In fact, rhetorically if not literally, "Hast thee" is a poem to a piece of paper. The "thee," "thou," and "you" of the poem indicate the none-too-hasty poem itself ("thou art to weake") (line 3), and it is only as "him" that the T.W. of the title makes an appearance. Donne's fourteen lines thus create a situation in which Woodward is the subject but not the object of address, continually referred to but never directly hailed by the poet himself. 
What we witness in "Hast thee" is apostrophe in its ancient sense of "a turning away" or diversion from one initial interlocutor to another (Alpers 3). In an exemplary discussion of Edmund Waller's equally apostrophic "Go, lovely rose," a Renaissance poem which, like "Hast thee," instructs a posted object to speak for the absent sender, Paul Alpers calls this rhetorical technique a strategic "deflecting" of address" (7). By turning away from the female recipient to the floral emissary, Alpers proposes, Waller's “speaker ... gives an air of graciousness and innocent desire to his pointed wit," making his arguments (in Waller's case, against virginity) "less insistent" (7). If we emulate Alpers and try replacing Donne's initial "him" with "you," we can witness this graciousness in action. Even in an age of passionate letter-writing between men (Bray 75; Brown Friendship 76-79; Saunders 61; Tosh 17), Donne may have hesitated before addressing an adolescent youth (and the brother of a close friend) directly as "you" "my payne \& pleasure" (line 2).

Yet, there is more going on here than simply an attempt to lessen the intensity with which Donne's desire for T.W. is made legible. In its exchange of a genuine interlocutor for a mute paper, Donne's apostrophe-and, indeed, all apostrophe, regardless of any sexual preference its speaker might express-offers a rhetorically queer form of resistance to what Barbara Johnson calls "straight speech" (30). As it happens, one effect of Donne's indirection is to render the same-sex nature of this desire transparent to other readers. Perhaps because of the telling presence of the third-person pronoun "him," "Hast thee" was less vulnerable to the heteronormatization experienced, for instance, by Donne's poignant epistolary sonnet in the second person beginning "At once from hence my lines \& I depart" (“To Mr. T.W.," line 1). Originally addressed to Thomas Woodward, “At once from hence" was transformed, in two early-to-mid-seventeenth-century transcripts, into a love poem addressed to "Madam” (Bodleian Library MS Rawl. poet. 116, f. 62v; Yale Osborn b 148, 4). But if this amendment signals the ease with which Donne's homosocial complaint could be mistaken, outside the purview of a knowing coterie, for hetero-amorous solicitation, it also exposes 
how, in its hailing of a posted page, "Hast thee" was also hailing precisely such a coterie. Donne's apostrophic "deflecting" of address in "Hast thee" is fundamentally a turn toward the "closed" masculine societies of Cambridge and the Inns of Court from whose memberships Donne drew his chief friends (Smith 104). Indeed, Donne gestures playfully to this close-knit, poetically literate allmale readership when he refers, in "Hast thee," to the "Men" who have debated the "place \& paynes of hell" (lines 7-8). These men have decreed not only Donne's but every man's damnation to be "privation / Of him" (emphasis mine) (lines 8-9), a figure so well known within this community that he need not be named. Donne's abjection is thus diverted through an entire fellowship afflicted by T.W.'s absence. What Klawitter fails to acknowledge when he identifies one-to-one intimacy as a hallmark of Donne's early verse letters is the poet's tendency to route homosocial feeling through such a community (7). Indeed, this community's norms-both poetic and affective-were partly responsible for shaping the unusual terms by which Donne and other members expressed desire. ${ }^{5}$

A powerful example of one such poetic norm is a commitment to "rugged" or irregular meter. This commitment is literally inscribed on the front page of a surviving packet of poems mailed to Donne during his brief employment as secretary to Lord Keeper Thomas Egerton. The sender, the essayist William Cornwallis, placed several bifolia containing a series of original "himnes" inside a rhyming "cover letter" inscribed in his sloping autograph hand (Bodleian Library MS Tanner 306 Vol. 1, f. 237r). ${ }^{6}$ This introductory poem draws a parallel between Cornwallis's verse offering to Donne and the "base" gifts of lambs and kids sacrificed to the pagan gods by "rusticke sheapheards" (lines 4, 1). "Soe offir I, my beast affection" he writes with a "bestial" pun (line 7), apparaled in these harsh totterd ryems think not they wante love, thowghe perfection or that my loves no triwer then my lyens Smuthe is my love, thowghe rugged be my vears 
yet well they mean, thowghe well they ill rehears (8-12).

The governing opposition of Cornwallis's poem is between well-meaning or "Smuthe" love for his recipient, and posted lines he describes as imperfect, "harsh," "rugged," and "totterd" (in early modern parlance, tattered or ragged). Homosocial affection is thus said to manifest itself through a series of unevenly stressed syllables, a misdirection which Donne's “direackt discerninge eye" (line 5) (and, perhaps, ear) must be trusted to recognize.

Cornwallis's faith in Donne's ability to glimpse what he calls "thir intent" (line 3) was justifiable, for there is considerable evidence of his reader's own preference for "rugged" rhymes. Donne's defiance of the even and flowing "numbers" advocated by his contemporaries generated a great deal of comment, perhaps most notoriously by Ben Jonson, who complained that "Donne, for not keeping of accent, deserved hanging”' (Larson 18, 22-23; Saunders 95). ${ }^{7}$ The self-professed "harshness" of Cornwallis's verse letter to Donne suggests, however, that such prosodic liberties were also appreciated and practiced within Donne's wider verse community. In fact, deploying rough meter seems to have been a means by which these male poets displayed their affective commitments to one another. For not only does Cornwallis's verse juxtapose different types of metrical feet and experiment with extra syllables, equally importantly, it calls attention to these unusual formal choices. This self-conscious depiction of prosodic failings was in fact a key strategy of Donne's early verse letters, one intended, I will suggest, to recode the erotics of male-male friendship.

Mismeasure's unlikely usefulness as a circuit for same-sex desire is not without precedent in Renaissance English literature. In his influential Latin-teaching manual The Scholemaster (1570), Roger Ascham suggests an intriguing connection between flawed prosody and a form of loving homosociality mediated by texts. A few pages into his second book, Ascham pauses to lament the death of his "deare frende," "bedfeloe," and Latin pupil John Whitney. Singled out for particular praise are Whitney's "choislie" and "orderlie" translations from (it can hardly be a coincidence) the 
consummate humanist discourse on friendship, Cicero’s De Amicitia (Sig. K4v). ${ }^{8}$ Reflecting on this still-fresh loss, Ascham reveals that "either love, or sorow, or both, did wring out of me . . certaine carefull thoughtes of my good will towardes him, which in my murning for him, fell forth, more by chance, than either by skill of use, into this kinde of misorderlie meter' (emphasis mine) (Sig. K4v). That the elegy in fourteeners which follows is actually quite metrically regular is beside the point. Ascham's portrayal of his rhymes as unskillful, haphazard, and "misorderlie" is intended to contrast painfully with Whitney's “orderlie” translations of Cicero. Without the textual and physical presence of the friend he twice calls "Myne owne John Whitney" (Sigs. K4v, L1r), Ascham has lost his flow.

By routinely adopting a language of poetic malformation through such adjectives as "harsh," “weak," "imperfect," or "lame" (a term Paula Blank glosses as containing "more or less than ten" syllables) (67), Donne, too, deploys mismeasure as another powerful proxy for the homosocial desires impelling these poems' transmission. Thus, when he confesses in "Hast thee" that his "harsh Verse" can only trot along on "to weake / feete" (two weak feet) (lines 3-4) "as fast as thy lame measure / Will give thee leave ..." (lines 1-2), what he is effectively describing are the painful effects of T.W.'s unresponsiveness. Donne, like Ascham, associates the metrically "perfect” line with loving collaboration between men. Allusions to bad form indicate failures of this sociality, resolvable only through a poetic reply to Donne's rhymes or a reparative act of reading on a friend's part (Saunders 78). Such a response is often cast quite explicitly as a corrective to Donne's formal deficiencies. For instance, in Donne's only non-sonnet verse letter to T.W., “All haile sweete Poet,” Donne’s assertion that his "Song" is "to'harsh for ryme" ("To Mr. T.W." line 25) generates the demand for a superior exemplum from his recipient. Writing modestly that his own lines "will be good prose, although the verse be evill" (line 27), Donne begs, with a phallic wink, for some better verses from T.W. on the one "Subject" "worthy thy quill": "A poeme in thy prayse \& writt by thee" (lines 21-22, 24). Only T.W., Donne suggests, can teach Donne how to praise T.W.'s “good parts” (line 19). 
Donne thus aspires, in formal terms, to "bee / Thy debtor, thy'Eccho, thy foyle, thy Zanee" ("an ineffective or burlesque imitator") (lines 29-30) (Milgate 60). By suggesting that the two men's relationship will be made legible in the aspirational likeness of his poetry to T.W.'s, Donne playfully adapts for non-human subjects the rhetoric of similitude often invoked to celebrate same-sex friendship pairs in the Renaissance (Masten Queer 73-74; Shannon Sovereign 2-3; Traub 327-31).

Yet, even as Donne's desire for T.W. and other young men is routed through allusions to irregular or harsh verses requiring a recipient's intervention, this queer poetics of mediation is compounded by an overlapping discourse of "straight" sexual reproduction (Meakin 26). Donne’s reference to his friend's impressive "quill," for instance, represents more than just manly banter. Not unlike Shakespeare, who was composing his "sugred Sonnets" for "private friends" around the time that Donne was writing his own fourteen-line epistolary verses to young men (Meres Sig. Oo1v), Donne represents the creative homosocial exchanges he craves through a curious discourse of insemination and childbirth (Sedgwick 35, 38). We catch a further glimpse of this proxy in "All haile" when Donne describes the "sweete Poet" T.W. as "more full of more strong fyre / Then hath or shall enkindle any Spiritt" (lines 1-2). If “sweetness" was crucial to "the syntax of affective male relations" in Renaissance England (Masten Queer 74), particularly in the familiar letters exchanged between humanist-educated men like Donne and his friends, "spirit" was a conventional euphemism for both "penis" and "semen" (Textual 141). Admittedly, as Richard Rambuss's careful readings of Donne's devotional verse remind us, we need not always imagine a vagina or womb to be the object of such a phallus. ' In fact, we might justifiably read the phrase "enkindle any Spiritt" (line 2) as an allusion to the erections of T.W.'s male readers. Nonetheless, by punningly describing the poetic efforts of other, inferior writers as "toughly Laboured" (line 6), Donne assigns to his friend's lines not only the sweetness proper to masculine epistolary exchange but a form of reproductive potency. 
What makes T.W. stand out from other poets, metaphorically speaking, is the ease with which he begets offspring in the form of new, more skillful lines.

Metrical and reproductive proxies intertwine in important ways in "Kindly I envy thy Songs perfection," a verse letter thanking T.W.'s brother Rowland Woodward for sending him a (now-lost) poem. Continuing the exchange, Donne applauds the balanced composition of R.W.'s "Song” by praising its construction from the four elements: earth, fire, water, and air. It is the poem's "Ayre," however, which produces the most unusual effects on its recipient:

as Ayre doth fulfill the hollownes

Of rotten walls; so it myne emptines.

Wher tost \& movd it did begett this sound

Which as a lame Eccho of thyne doth rebound.

Oh I was dead: but since thy song new life did give

I recreated even by thy Creature live ("To Mr. R.W.," 9-14).

Several features of this poem stand out. First, Donne refers to his composition (the very verse letter R.W. reads) as "lame" (line 12), a formally inferior piece of writing to that he has received from R.W., and an implicit demonstration, as I have shown, of Donne's need for reassurances of love across distance. Second, Donne once again calls his verse letter an "Eccho" (line 12), implying a causal relationship between R.W.'s transmission and his own composition. Finally, Donne depicts R.W.'s verse quite overtly as his impregnator. In the sixteenth century, the verb "fulfill” (line 9) could literally mean to "fill." Here, the potency of R.W.'s verse fills Donne’s “emptines" (line 10), an emotional state Donne equates with a hollow wall, with the "sound" (line 11) of a new poem. But Donne's use of the term "begett" and, a few lines later, "new life" (lines 11, 13), makes it clear that the hollow space in which R.W.'s lines are "tost and mov'd" (line 11) is also a womb. That Donne's offspring is lame or less formally "perfect" (line 1) than the virile text which fathered it may thus 
speak less to a failure of homosociality than to an ancient belief that the conceiving mother (in this case, Donne) produced a less robust form of semen than her male partner (Finucci 48).

Denaturalizing the teleology of reproduction has been and continues to be an important aim of queer theory. ${ }^{10}$ Donne's poems to readers like the Woodward brothers force us to consider how, as a signifier of male homosociality, sexual generation might also be queer. For instance, in an age that stigmatized visible deformity, Donne's insistence on the lameness and unviability of his poetic offspring contradicts the associations of social usefulness inherent in other Renaissance portrayals of verse as children (Guy-Bray 35). Indeed, Donne's vision of two men's poetic reproduction sits uneasily beside contemporary models of masculine literary pregnancy. Observing the frequency with which male writers align "poetic and intellectual endeavours" with the womb, paradoxically "the very organ that is supposed literally to chill and dampen the female intellect," Katherine Eisaman Maus suggests that the invisibility or inaccessibility of the womb's interior made it an empowering model of "poetic identity and freedom" for many Renaissance poets (268, 273-74). Yet, if Donne’s use of reproductive tropes indicates his knowing participation in this longstanding literary tradition, it also exposes his radical departure from that tradition's symbolism. For far from being selfcontained and inscrutable, the womb proves, in Donne's verse letters, to be a highly visible and communal space. Indeed, Donne utterly rejects the possibility of "pregnancy without impregnation" implicit in verses such as Sir Philip Sidney's famous Astrophil and Stella Sonnet 1 (Maus 275), in which the poet is told that he already possesses the capacity to go forth and multiply: "look in thy heart and write" (line 14). Instead, Donne's womb becomes an unexpectedly fertile (pun intended) trope for all-male sociality and the textual collaboration it entails. Only through regular intercourse (a term which in early modern England primarily meant "conversation") can Donne conceive (or conceive of) what amount to healthy poetic offspring (Masten Queer 83). 
This queer deployment of the female womb as a proxy for affective male collaboration is ostentatiously pursued in a fourteen-line verse letter to “L. of D.," probably Donne’s Lincoln's Inn friend William Stanley, Lord Derby. Unusually, Donne's address to Stanley introduced a gift of five additional verse letters (Starza Smith 176-77, 184). ${ }^{11}$ These poems were originally addressed to “T.W.," "R.W.," and “C.B."-that is, to the Woodwards and Donne's chamber-mate at Lincoln's Inn, Christopher Brooke. What's surprising about the poem to "L. of D.," therefore, is its attribution of all six poems' paternity-plus that of an unknown seventh, too premature or formally inadequate, it would seem, for circulation-to the "rhyme" Donne has received from Stanley:

See, Sir, how as the suns hott masculine flame

Begetts strange creatures on Niles durty slime,

In me your fatherly yet Lusty rhyme

(for these Songs are the fruit) have wrought the same.

But though th'engendring force from whence they came

Be strong inough, and nature do admit

Seaven to be born at once, I send as yet

But six, they say the seventh hath still some maime (“To L. of D.," 1-8).

In Sonnet 31, Shakespeare memorably depicts his male addressee as the embodiment of all the friends he had thought lost. Here, Donne suggests (even more perversely) that his former exchanges with male friends are renewed through his own insemination by Stanley's lines. Like the life-giving or "masculine" sun (line 1), a precursor of the famous "masculine persuasive force" (line 4) Donne’s speaker attributes to his seductive words in "Eleg: 11" (“To His Mistress on Going Abroad”) (a poem also copied in the Westmoreland Manuscript), Stanley's poem "Begetts" new and previously delivered rhymes “In” Donne (lines 2-3) (emphasis mine). Donne’s oddly interiorizing preposition reiterates his claims to feminine anatomy, while simultaneously insisting on the womb as a site of 
homosocial communion. Donne's body, in short, is a place in which poems are "wrought" (line 4) by other men. That the "engend'ring force" (line 5) which resulted in this multiple pregnancy was, not incidentally, a source of pleasure for Donne is attested by his description of Stanley's verse as both "fatherly" and "Lusty" (line 3)-the latter meaning not only vigorous but full of desire.

It is an unhappy accident of the archives that many of the poems Donne depicts as pleasurably "fathering" his own verses were not shown the same care as the verse letters in Donne's oeuvre. Yet, one poem addressed to Donne during his Lincoln's Inn period does survive. Its preservation in the Westmoreland Manuscript may stem partly from the fact that its author was none other than Thomas Woodward, the copyist's brother. In his verse letter "To Mr J.D.", the "sweete Poet" T.W. indicates his willingness to enter into a lyric friendship with Donne. In the process, however, he offers his own unusual twist on Donne's poetics of mediation. Deploying rough meter and pregnancy as proxies for the currents of homosocial desire circulating between himself and the older, more (poetically) experienced Donne, Woodward nonetheless diverges from Donne's model by representing their exchange as a sexual encounter entirely devoid of men.

T.W.'s poem opens, familiarly enough, by tracing his verse's genealogy. “Thou sendst me prose \& rimes," Woodward writes, "I send for those" (that is, in exchange for those), "Lynes, which beeing nether, seeme or verse or prose" (lines 1-2). Donne's gift of prose and poetry has begotten on Woodward a hybrid prose/verse text, one whose lines, he claims, "are lame \& harsh, \& have no heat at all / But what thy liberall beams on them let fall" (lines 3-4). But if the supposed "lameness" and "harshness" of Woodward's rhymes is put forward as evidence of his poetic inferiority to Donne, their mimicry of Donne’s language-“to’harsh for rhyme," “a lame Eccho," "Hast thee harsh Verse, as fast as thy lame measure"-insists on Donne's paternity. Because of men's "hotter" nature, "children were supposed to resemble their fathers more than their mothers" (Finucci 48). 
Woodward's association of Donne with "fyer" (line 5), "heat" (line 3), and sun-like "beams" (line 4) proves metrical irregularity to a source not of difference but of family resemblance. ${ }^{12}$

But whose bodies are actually involved in the generation of Woodward's verse letter? Here is how T.W. describes his poetic stimulation by the lines he has received from Donne:

Have mercy on me \& my sinfull Muse

Which rub'd and tickled with thyne could not chuse

But spend some of her pithe \& yeild to bee

One in that chaste $\&$ mistique tribadree.

Bassaes adultery no fruit did leave,

Nor theirs which their swolne thighs did nimbly weave,

And with new armes \& mouthes embrace and kis

Though they had issue, was not like to this.

Thy muse, Oh strange \& holy Lecheree

Beeing a Mayd still, gott this Song on mee ("To Mr J.D.," 11-20).

In this remarkable passage, Woodward could be seen as offering a more direct account of the erotics of homosocial exchange than we have yet encountered. Yet, T.W.'s verse letter resists an obvious one-to-one analogy between sexual partners and poets. It does so by, astonishingly, by mediating these erotics through two female bodies. "Rub'd", "tickled," "tribadree” (lines 12, 14): what T.W. is describing in his verse letter is in fact a steamy if non-penetrative ("chaste" in the most literal sense) (line 14) lesbian encounter between Donne's and T.W.'s poetic Muses (Andreadis 45-46, Traub 25). Perhaps T.W. was inspired by Donne's brief injunction, in another verse letter to his brother Rowland, to "joyne then thy Muse with mine / For myne is barren thus devorced from thyne" (To Mr. R.W., “Zealously my Muse,” lines 13-14) (Meakin 67). Alternatively, Donne may have borrowed this image of conjugal Muses from T.W. himself. More prominently at work here than in Donne's 
poem to Rowland Woodward, however, is a disparate power dynamic between T.W.'s Muse, the passive figure who "yeild[s]" and "could not chuse" (lines 12-13) but succumb to sexual stimulation, and the more explicitly tribadic Muse belonging to Donne (Klawitter 10). Familiar to the classically educated poetic communities of Cambridge and Lincoln's Inn from verses such as Martial's epigram on the woman-loving Bassa, the tribade was a threatening sexual type who appropriated masculine privileges by pleasuring other women with her enlarged clitoris (DiGangi 60-63; Meakin 64; Traub 17, 194, 210, 330). By depicting his Muse as the partner who is "rub'd and tickled" (line 12) by Donne's more assertive tribade, Woodward thus rejects the symmetry ascribed to lesbian eroticism in contemporary works such as Donne’s own “Sappho to Philaenis" (Traub 330, 339).

Yet, it is precisely the inequality of this encounter, Woodward suggests, which makes it so generative. ${ }^{13}$ In Donne's same-sex Ovidian reimagining, Sappho seduces her partner by denigrating the divergent sexual experiences of men and women: the female partner must endure the "tillage of a harsh, rough man" (Robbins ed., "Sappho to Philaenis," line 38). Lesbian pleasures, on the other hand, are mutual, a quality Sappho elides with invisibility: "of our dalliance, no . . signs there are” (line 41). In T.W.'s account, by contrast, the "strange \& holy Lecheree" (line 19) of Woodward's and Donne's unequal Muses "leave[s] behind them that which their sin shows" "'Sappho to Philaenis" line 39). Not only does T.W.'s muse "spend ... her pithe" (line 13)-another reference to the semen women were believed to ejaculate during orgasm-her pleasure results in "issue" (line 18): the very poem Woodward sends Donne is borne by Woodward himself. This paradox is reinscribed in a textual crux deriving from “To Mr J.D."”s seventeenth-century circulation. In Bodleian Library MS Eng. poet f. 9, a miscellany containing two copies of Woodward's verse to Donne, Woodward's "rub'd and tickled" has been copied out as "rough'd and tiled" (16) and, later on, "rough'd and tieled" (73). "Tiled," a variant of "tilled," suggests that "harsh" "tillage” ("Sapho to Philaenis" 38)- 
the necessary cultivation of the land to prepare it for new crops-was precisely what some compilers envisioned when they pictured the Muses' lesbian contact.

By eliding the uneven sexual dynamics between the two men's Muses with Woodward's own surprising capacity to bear "fruit" (line 15)_“"Thy muse," he explains, "gott this Song on mee” (line 20)-Woodward can ultimately be seen as rejecting Donne's implication that he, T.W., possesses either poetical or emotional dominance over Donne. Lest we find ourselves becoming inured, however, to the breathtaking array of proxies Woodward deploys in this brief poem, let us take a step back and acknowledge that a depiction of lesbian Muse sex resulting in a male poet's pregnancy is a remarkably tangential way to reshape the dynamics of a friendship between two men. Why indulge in such an elaborate re-circuiting of same-sex desire? Why not just "come out" and say it?

\section{II.}

Woodward's fantastical remapping of reproductive roles onto the wrong bodies via the erotics of two Muses epitomizes the queer poetics of mediation I have charted across the poems of Donne and his friends (a poetics which must necessarily remain partial). ${ }^{14}$ In the space remaining, I would like to offer two possible explanations for the queerness of the formal strategies I have been unfolding. Both explanations derive, crucially, from the limitations placed upon Donne and other members of his community by the socio-textual circumstances in which they shared their verse.

The first source of Donne's queer poetics is the poet's and his friends' routine reliance, in their exchanges of lines, on what essentially amounted to textual proxies. Here, I am referring to the literal posted papers which were once inscribed with the verse letters we now read in codex form. For if Donne's poems to Cambridge and Lincoln's Inn men represent some of the earliest experiments in modern English within the verse epistle genre (Maurer 235), they nonetheless 
responded not only to Ovidian and Horatian models but to the rather more mundane conventions of the early modern post. A poetics of mediation was particularly appropriate, I propose, to a form of sociality which relied in large part on a series of mediating epistolary objects.

Surviving documents like the poetic packet sent to Donne by William Cornwallis are evidence of a historical reality which, despite being widely recognized by Donne scholars, has had remarkably little impact on close readings of his verse. This reality is Donne's and his friends' use of mail as their primary mode of poetic circulation. The postal superscription on Cornwallis's rhymes, "To my ever to be respeckted freand Mr John Done Secretory to my Lorde Keeper give these" (Bodleian Library MS Tanner 306 Vol. 1, f. 238r), shows us that the "To" in the titles of Donne's verse letters once indicated more than a pretense of spoken address. More often than not, this preposition points to the postal trajectory of a verse from the hands of its sender to those of a recipient. The only known holograph poem by Donne, a verse letter folded into a tiny packet and addressed to an English gentlewoman, followed just such a path. ${ }^{15}$ Indeed, the titles of some manuscript copies of this poem betray the verse's postal origins through their similarity to the holograph's still-visible superscription, "To the Honorable lady the lady Carew” (Beal, CELM).

Many of Donne's verse letters were epistolary, then, not only in genre but in material form. Admittedly, the tendency of these posted verses to emulate their ephemeral prose cousins by taking the shape of a single folded sheet or half-sheet has made them vulnerable to disappearance and decay over time. Yet, we routinely catch glimpses of Donne's and his friends' paper proxies in printed collections and manuscript miscellanies like the Westmoreland Manuscript, whose transcriptions on safely bound pages represent a later incarnation of those artifacts. Thomas Woodward's allusion to Donne's "prose \& rimes" is a good example of such a glimpse. Easily mistaken for an aesthetic judgment echoing Donne’s own assessment, in "All haile sweete Poet," that his verse is little more than rhymed prose, this phrase actually points to something more literal: 
the textual objects Woodward originally received from Donne. Donne's “prose \& rimes" were probably two distinct sheets, a poetic enclosure tucked inside a prose letter. Donne's later correspondence bears witness to this material practice. In a letter to his close friend Sir Henry Goodere, for instance, Donne notes that he has enclosed "another ragge of verses, worthy of that name for the smalnesse, and age, for it hath long lien among my other papers" (Donne 88). ${ }^{16}$ On another occasion, he writes, "I Send you here a Translation" (207), referring to a copy of the "Lamentations of Jeremy" included on an interior sheet for separate circulation (Starza Smith 214). When T.W. confesses, then, that he returns to his friend "Lynes, which beeing nether, seeme or verse or prose" (“To Mr. J.D.” line 2), he represents the process by which two pieces of paper from Donne have generated a single sheet.

Donne's punning conclusion to a verse letter for his friend Sir Henry Wotton, To know my Rules, I have, and you have

$$
\text { Donne (“To Mr H.W.," 70-71) }
$$

represents another occasion in which the original physicality of the paper proxy, sent to Wotton upon his return from continental travels, may be made visible even in the poem's transcribed or published form. By causing the last word of his poem to emulate a postal signature, Donne exposes the material relationship between his message and its medium: a sheet of paper folded, sealed, signed, superscribed, and sent as a letter. “Sir, More then kisses, Letters mingle Soules,” Donne’s poem to Wotton famously begins (line 1). This familiar sentiment would seem to apply, too, to the other rhymed "Letters" which were among Donne's earliest stock-in-trade.

A verse letter for Rowland Woodward further reminds us that all of the poems Donne wrote to friends participated in the deeply embodied customs of early modern epistolarity. These practices included the impressing and breaking of seals, the folding and unfolding of sheets, and even the intermingling of ink on paper as a recipient endorsed with his quill a verse inscribed by his friend. 
Writing to Woodward from Plymouth Harbor after foul weather had aborted his first attempt to sail in Ralegh and Essex's fabled "Islands Expedition" against Spain in the summer of 1597, Donne describes in intimate detail his "letter"'s possession of "my name, words, hand, feete, hart, mind, \& witt" (“To Mr R.W.," "If as myne is thy life a slumber bee," lines 5-6). Here, Donne draws attention to the presence of two essential epistolary elements: his signature ("name") and his own writing ("hand"). The signature was an authenticating feature, which Donne typically concluded with the figure of a Greek epsilon resembling an hourglass. ${ }^{17}$ Donne’s poem to Woodward would literally have worn this "Shape" (line 4) just as, in the opening lines of the poem, the god Morpheus is said to wear the guise of mortal men in dreams. The use of one's own handwriting (rather than that of a scribe) was, meanwhile, an affectively charged choice associated with the sender's body and hence with familiarity between correspondents (Schneider 121). Small wonder, then, that posted verses like those of Donne and his friends were represented as tactile surrogates for emotional commitments in the world beyond the text ("Accept these lines, and if in them there be / Meritt of Love, bestow that Love on mee" (lines 13-4), Donne writes to T.W. in "At once from hence"). Mailed versions of Donne's verse letters were desirable not only as rhymes but as a means, however insufficient, of giving sender and reader mutual access through the medium of the posted page.

Yet, when Donne writes, in "At once from hence," that "from unhappy mee, things happy are sent" (line 11), he means this statement quite seriously. For if these early verse letters are fundamentally about the desire for emotional closeness, the physical closeness which sustained these relationships too often remained, as Donne's parallel construction suggests, a near-impossible condition. As long as Donne was separated from his male friends, as he would often be throughout the politically turbulent 1590 s and during the painful years of effective exile following his unauthorized marriage to Ann More, Donne's contact with these loved men would necessarily be mediated by mail (Colclough). Circuitous poetic structures such as sexualized female bodies, ripe 
wombs, failed prosody, and diversions of address thus speak to the lived contingencies of early modern friendship. At a time when travel was difficult and political ambitions might take up-andcoming young men not only to London but to remoter locations (Cadiz, Ireland, France, Venice, rural England), how could Donne's desire for his friends be anything but routed through a continual series of proxies? In one sense, then, Donne's queer, diversionary poetics are the formal expression of a homosocial erotics dependent on emotionally resonant but ultimately inadequate postal texts.

But Donne's poetics of mediation also represents, I believe, an attempt to disguise a potentially more disturbing aspect of this epistolarity: its practitioners' continual and complete reliance on a living intermediary. This figure appears in Donne's early verse letters only once, in the little-circulated poem to Sir Henry Wotton, "Henrico Wotton in Hibernia Belligeranti." Sent during Wotton's 1599 service in Ireland under the second Earl of Essex, Donne's lyric couches his familiar wish for a homosocial exchange of texts in unfamiliar terms:

I ask not laboured letters which should wear

Long papers out, nor letters which should fear

Dishonest carriage, or a seer's art,

Nor such as from the brain come, but the heart (Robbins ed., 17-20.) Augmenting Donne's fear that his friend's reciprocation of his own loving missives will become a burdensome duty is a more serious source of anxiety, "Dishonest carriage" (line 19). What really concerns Donne is the trustworthiness of a heretofore unseen figure: the bearer.

Ironically, the letter bearer was normally a highly visible presence in Renaissance England. Pages of rhymes were composed on the subject of Cambridge University's long-serving mail carrier to London, Thomas Hobson. More prosaically, correspondence from the sixteenth and seventeenth centuries testifies to the enormous impact of bearers on early moderns' daily lives. ${ }^{18}$ Turning to Donne's surviving prose correspondence, we find that he refers to the transmission of letters and 
other materials by a bearer approximately ninety times. In this, at least, Donne was typical of his contemporaries. For in an age with no standing post for private citizens (Daybell 129), the question of how one would send and receive messages was a serious preoccupation. Indeed, so unusual were opportunities for swift and easy communication that these rare occasions become one of Donne's favorite jokes. "I have but small comfort in this letter; the messenger comes too easily to me, and I am too sure that the letter shall be delivered," Donne writes of his bearer to Bridget White. "All adventures towards you should be of more difficulty and hazard" (5). By equating "hazard" and unreliability with merit and strength of feeling, Donne jestingly transforms into a chivalrous compliment the very real possibility that his earlier mail to her has been lost en route. The labor of the bearer, effaced in verse letters that imagine poetic lines departing across the landscape of their own agency, is brought sharply into focus here as Donne considers his mail's fate.

Reflecting on the practical means by which he might "absent speake" ("To Mr H.W.," "Sir, More then kisses," line 2), Donne exposes a whole network of intermediaries including servants, friends, relatives, passers-by, and public carriers driving fixed routes between London and more provincial destinations (Brayshay 52). To read Donne's mail, as it were, for the bearer, is thus to begin appreciating the extent to which the availability or unavailability of a reliable intermediary conditioned various aspects of Donne's communications with his patrons, relatives, and friends. For instance, Donne wrote a letter to Sir Henry Goodere every Tuesday during his lonely period of career paralysis at Mitcham not because the day itself had any special emotional significance, but because this schedule accorded with the weekly appearance, at the Rose Inn in Smithfield, of the public carrier who delivered mail to the town nearest Goodere's estate (Stewart 440). So much did this routine govern Donne's letter-writing habits that diversions from the pattern generated comment. Addressing Goodere, unusually, on a Saturday, Donne apologizes for "mak[ing] short payment of this duty of letters" (66). He explains that the unexpected arrival of Goodere's "man" 
(servant) (66) with correspondence from Goodere prompted him to take advantage of the unexpected chance to send a letter of his own.

Worth noting here are the formal effects of Goodere's messenger. As Donne himself observes, the "mans haste" to make his return journey "cuts off" or keeps the letter unusually short (66). Indeed, in Donne's prose correspondence, we typically find "haste" associated not with emotional urgency, as in the verse letter "Hast thee harsh Verse," but with contingencies of dispatch that justify a scanty message. "Haste" routinely curtails the flow of Donne's writing as its bearer points out the limitations of his or his horse's "weake / feet" ("Hast thee" lines 3-4). For on the "rough" and "rugged" roads of pre-modern England, "lameness" was a real concern. Departing too close to nightfall could have catastrophic consequences for the people and animals involved in the carriage of mail. Donne's language of deformed meter thus relies on a set of terms more suitable to the embodied realities of the carriers of letters and other goods in the Renaissance.

Ironically, poetic proxies such as limping form disguise a figure so important to Donne that he is often referred to by name. "I write to you by Mr. Pory" (126), Donne tells his recipient in one letter; elsewhere, "Mr. W. Stanhope ... did me the favour to undertake the delivery of it to you" (152); "This is my third letter . . which I sent by Spelty" (179); "I receive . . your letter by a servant of Sir G. Gresely" (179); "I had a Letter Pacquet from you by Mr Roe" (191); "those Letters which you sent by Captain Peter found me at $S p \hat{a}$ ' (251). Donne also describes his messengers in terms of their relationship to his addressee: "Your Son left here a letter for me" (148); "Lest your Polesworth carrier should cousen me, I send my man with this letter early to London" (53). On occasion, Donne himself even becomes the messenger. "I was at London, where I delivered your Letter for Sr. Ed. Conway, and received another for you" (34); "I came bold according to [Lord Chandos's] direction to address as many letters, as come to my hands for him, to yours” (British Library Add. MS 72346, f.57r); "I thought I might be pardoned, if I thought my self your man for that service to open it, 
which I did, and for the Letters I will deliver them" (216). In this last example, Donne likens himself to the servant of Goodere's who brought him mail on a Saturday.

Identifying one's bearer was important, for Donne and his contemporaries continually worried about the ease with which a bearer might become a reader. "You know me without a name, and I know not how this Letter goes" (217), Donne signs off cryptically in one letter to Goodere detailing the latest news from court. What Donne means here is that he cannot fully rely on the discretion of the carrier, or perhaps even of that of the personal servant he may have employed to take the letter to the Rose at Smithfield for collection by this professional carrier. In other letters, Donne makes his concerns more overt. He writes to a friend, probably Goodere, "It is my third Letter: which I tell you, because I found not Mr. Rogers, but left the Letter which I sent last, with a stranger at Cliffords Inne" (143). Donne raises the possibility that the "stranger" he has been compelled to employ may not have been fully trustworthy with regard to Donne's second letter. Writing again to Goodere from Paris, Donne comes even closer to accusing a messenger of misdirecting or misplacing his mail. "That Cook of which you writ to me, is come hither, and hath brought me other Letters, but not those of which you writ to me," he complains (132). In the future, Donne suggests, Goodere should select a more trustworthy intermediary for cross-Channel communications, such as "Mr Bruer at the Queens Arms a Mercer in Cheapside: he shall alwaies know where we are" (133). Here, Donne reveals his reliance not only on English networks of delivery but on ancient fellowships of merchants who had, from medieval times, cultivated systems of "postal agents" and reliable intermediaries across the continent (Beale 189). In these and other letters, we witness Donne making concerted efforts to control the personnel involved in epistolary transmission, or at least to provide mechanisms that would allow his recipient to identify an unreliable messenger. We should hardly be surprised, then, that on the sole occasion in Donne's 
verse letters in which we catch a glimpse of a bearer, he becomes a nexus for Donne's anxieties about safe carriage.

But if a bearer had the potential to become an illicit reader, it was equally possible for a recipient to become an intermediary himself. Sometimes this is precisely what Donne desires: "I pray deliver this Letter according to the addresse" (294); "in stead of a Letter to you, I send you one to another (117); "I shall be bold to deliver my poor Letters to her Ladiships hands, through yours" (95-96). On other occasions, however, it becomes clear that one of Donne's recipients has passed on mail without his express permission. "I have now much just reason to imagine, that some of my Pacquets have had more honour then I wished them: which is to be delivered into the hands of greater personages, then I addressed them unto" (126), Donne writes rather testily to Goodere. What Donne ostensibly portrays as a failure of understanding on the part of the bearer is, in reality, a failure of discretion on the part of Donne's most frequent recipient of both prose and verse (Starza Smith 205-07, 292). " $\Pi$ n them I may speak to you in your chamber a year hence before I know not whom" (114), Donne writes, with justifiable concern, of his letters to Goodere.

Donne makes a similar implication in a later verse letter to Rowland Woodward traditionally interpreted as a "refusal" to send a requested poem. In former days, Donne suggests, his Muse had dallied happily with that of his friend. Now,

Like one who'in her third widowhed doth profes

Her selfe a Nun, tir'd to retirednes

So affects my Muse now, a chast fallownes.

Since She to few, yet to to many hath showne

How Love song Weedes, \& Satirique thornes are growne (“To Mr. R.W.," 1-5). 
Donne's opening lines amount to another joke at his own expense. Though he has allowed his (potentially subversive) erotic elegies and satires to reach only a "few" readers, they have nonetheless been seen by "to many" (line 4) (Starza Smith 179). Donne's point is that, like a thrice-married woman's decision to take the veil, the "chast fallownes" which he attributes to his "Muse" (line 3) in response to Woodward's request for verse is a little belated. In effect, what Rowland's brother Thomas had called these muses' secret or "mistique tribadree” (“To Mr J.D.," line 14) was not as hidden as Donne had thought. Others, excluded from the intercourse between Donne and his recipients, have nonetheless managed to gain access to these poems. ${ }^{19}$

Behind Donne's poetics of mediation, then, lie concerns about precisely what it means to communicate with a friend across distance. Using a servant, acquaintance, or one of the professional carriers attached to Lincoln's Inn to pass on rhymes to one of the young men Donne loved and admired meant risking a fundamental miscarriage of these lines-a real problem for Donne since, as I have suggested, the norms and conventions of Donne's poetic community differed from those of other readerships (Patterson 42). ${ }^{20}$ When Donne turns from T.W. to address his paper in "Hast thee harsh Verse," he glosses over the fact that the real recipient of his instructions is, of course, the bearer. But even when Donne employed a trusted messenger, the risk of addressing an unintended audience remained. As Donne's letters to Goodere and his poem to Rowland Woodward, "Like one who'in," demonstrate, Donne could never be fully certain that T.W., R.W., and all the rest of his addressees would not become intermediaries in turn. The sheer volume of early modern manuscript witnesses to Donne’s poems, approximately 4,200 at last count (including 700 verse letters) shows that Donne's concerns about such unauthorized circulation were warranted (Starza Smith 175). Yet, even Donne's well-documented fear that his poems would fall into the wrong hands does not fully account for the recurrence of a poetics of mediation in Donne's early verse letters. For what the intermediary fundamentally represented for Donne, I believe, was his own inability to 
control the development of his relationships with the men who surrounded him, and subsequently departed from him, during the formative years of his early adult life. Donne's prose letters and even his slightly later verse letters such as the anxious poem to Wotton in Ireland show that the shape of a friendship might be determined not only by Donne's relentless desire to make contact, and his correspondent's varying willingness or unwillingness to write back, but by the more pragmatic issue of an intermediary's availability and reliability. The presence, status, and identity of Donne's bearersincluding those intermediaries who were also Donne's friends, and Donne's friends who were also intermediaries-had real effects on what and how much he could say, and how he said it. In short, these mediating figures determined whether his verses really could, as he would write in a later prose letter, serve as "conveyances and deliverers of me to you" (109).

In his strange, passionate, playful, abject, and too-often neglected early verse letters, Donne attempts to replace the real figure of the bearer with a series of imagined intermediaries whose nature and function he can define. In this, I propose, Donne's poetics are more queer, and Donne less queer, than Klawitter wants to suggest. For what these poems' formal recircuitings of desire ultimately disguise is the silent presence of a third participant in each same-sex poetic coupling. Whenever Donne expresses homosocial longings in a fashion we find indirect, or downright tangential, what is actually being covered up is this sender's very real need for another "man." Such elaborate reroutings of the currents of loving friendship show, however, that this intermediary figure made Donne deeply wary, to the point that his presence, so visible in Donne's prose correspondence, is almost entirely erased in Donne's verse letters. In practice, then, the early-career Donne resisted the "shared" intercourse that postal exchange in Renaissance England almost inevitably entailed (Daybell 200). In his Holy Sonnet 18 ("Show me, dear Christ ...”), which appears only in the Westmoreland Manuscript, Donne speaks provocatively of being “open to most men" (line 14). But this hope was never Donne's. 


\section{NOTES}

I would like to thank Thomas Ward and Scott Trudell for organizing the generative 2017 Shakespeare Association of America Seminar, "Queer Meter," which prompted me to write this essay. I am especially grateful to the responses of seminar members Bellee Jones-Pierce, Alicia Andrzejewski, and Christopher Shirley. Shirley's comments were particularly valuable in helping me to articulate the essay's eventual argument. I would also like to thank our seminar's respondent, Jeffrey Masten, for his thoughtful feedback. Ali Madani and Marissa Nicosia generously offered assistance in the essay's final stages. Final thanks are due to Alan Stewart, to my anonymous second reader, and to the editors at JEMCS for their encouragement.

${ }^{1}$ New York Public Library, Berg Collection, Westmoreland MS. Unless otherwise noted, poetic quotations are taken from images of the pages of this manuscript, available at DigitalDonne: The Online Variorum. Abbreviations, except for " $\&$," have been silently expanded.

2 I have placed the word "pawnes" in brackets because, although it appears in contemporary manuscript copies of the poem, the Westmoreland Manuscript contains a blank space where this word should go. This omission results not from censorship but more likely from an illegibility in Rowland Woodward's source text. The other two verse letters in the Westmoreland Manuscript featuring censorship are the poems, both entitled "To Mr. T.W.", beginning “All haile sweete Poet” and "At once from hence."

${ }^{3}$ I want to make it clear that I am in no way dismissing Donne's language, in the manner of Herbert Grierson, as "the polite fashion of the day" (165). My point is not that describing these poems as expressions of deep friendship erases the potential for eroticism, but that we need to widen the terms by which we define friendship, acknowledging that affective and sexual same-sex desires were (and are) part of such relationships.

${ }^{4}$ For a discussion of one of Donne's much later verse letters that does incorporate a sustained analysis of the conditions of its transmission, see Brown, Presence 78-83. 
5 Donne's verse illustrates Rebecca Ann Bach’s important claim that “English Renaissance representation shows us a world in which male homosocial desire is primary rather than secondary or implicit” (9).

${ }^{6}$ On the "himnes," see May 454-55.

7 See, for instance, Dudley, Third Baron North's critique of "strong lines" (5). Perhaps the clearest formal account of the nature of Donne's rough meter is Stein's.

8 On Ascham's depiction of Whitney, Cicero, and structures of friendship, see Shannon, Sovereign 2324.

${ }^{9}$ See Rambuss 35-6.

${ }^{10}$ See, most famously, Edelman, but also Berlant and Warner, whose essay (as Stephen Guy-Bray notes) predates No Future.

11 Although I accept Starza Smith's identification of William Stanley as the recipient of these six verse letters, other addressees and accompanying rhymes have been posited. Robin Robbins proposes William's elder brother Ferdinando Stanley as the recipient and interprets Donne's term "Songs" literally as a reference to a selection of the poems usually called "Songs and Sonnets," a number of which (ex. The Message, The Bait, Sweetest) were set to music. Confusingly, Robbins notes, the poem appeared in print (based on non-holograph manuscripts) in 1633 under the title "To E. of $D$. with six holy Sonnets," but modern editors and critics have argued against the likelihood that any of Donne's mature holy sonnets accompanied this youthful verse (4243). An exception is Helen Gardner, who posits that the first six holy sonnets printed in 1633 were the accompanying gift. She also identifies their recipient as Richard Sackville, Earl of Dorset (Divine Poems 64).

12 On early modern literary collaboration as an attempt to erase difference, see Masten, Textual 17-19. Masten also discusses the paradox of male-male generation without a separate mother in his discussion of the poetic responses to the publication of the Beaumont/Fletcher dramatic folio; see especially Textual 136.

${ }^{13}$ On Donne and Woodward's fertility versus tribadism's sterility, see Andreadis 46. 
14 One could, for instance, trace Donne's frequent use of salvific imagery, deployed most provocatively in "Hast thee harsh Verse" through Donne's allusion to "Creator" and "Savior," as another mediating structure.

15 This manuscript is Bodleian Library MS Eng. poet. d. 197. See also Gardner, Holograph.

16 All quotations from Donne's prose letters are taken from the 1651 volume of Donne's Letters to severall persons of honour unless otherwise noted.

${ }_{17}$ See, for example, British Library Add. MS 29598, f. 13r; British Library Cotton MS Cleopatra F. VII, f. 293r.

18 A memorable instance of this impact may be seen in Dorothy Osborne's remark in a 1653 letter to her lover William Temple, "Your last letter came like a pardon to one upon the block. I had given over hopes on't, haveing received my letters by the other Carrier, whoe uses always's to bee last. The losse put mee hugely out of order, and you would both have pittyed and laught at mee . . in comes my blessed Boy with your letter, and in Earnest I was not able to disguise the Joy it gave mee" (75).

${ }^{19}$ Evidence of this exposure can be found in Francis Davison's much-cited inclusion of “satyres, elegies, epigrams \&c. by John don." in a list, compiled before 1608, of "Manuscripts to gett." See Marotti 16. 20 "Be circumspect by whom you write, and fit your packet to the messenger," the father of Inns-ofCourt scholar John Holles advised his son. See Beale 128.

\section{Works Cited}

\section{Manuscripts}

Bodleian Library MS Eng. poet. d. 197

Bodleian Library MS Eng. poet f. 9

Bodleian Library MS Rawl. poet. 116

Bodleian Library MS Tanner 306 Vol. 1 
British Library Add. MS 29598

British Library Add. MS 72346

British Library Cotton MS Cleopatra F. VII

British Library Cotton MS Julius C. III

New York Public Library, Berg Collection, Westmoreland MS

Yale MS Osborn b 148

\section{Printed Sources}

Alpers, Paul. "Apostrophe and the Rhetoric of Renaissance Lyric," Representations 122.1 (Spring 2013): 1-22.

Andreadis, Harriette. Sappho in Early Modern England: Female Same-Sex Literary Erotics 1550-1714. Chicago and London: Chicago University Press, 2001.

Ascham, Roger. The Scholemaster. London, 1570.

Bach, Rebecca Ann. Shakespeare and Renaissance Literature Before Heterosexuality. New York: Palgrave Macmillan, 2007.

Beal, Peter. Catalogue of English Literary Manuscripts 1450-1700 (CELM). Web. 9 August 2017.

Beale, Philip. England's Mail: Two Millennia of Letter Writing. Stroud: Tempus, 2005.

Berlant, Lauren, and Michael Warner. "Sex in Public.” Publics and Counterpublics. Ed. Michael Warner. New York: Zone, 2002. 187-208.

Blank, Paula. Shakespeare and the Mismeasure of Renaissance Man. Ithaca and London: Cornell University Press, 2006.

Bray, Alan. The Friend. Chicago and London: Chicago University Press, 2003.

Brayshay, Mark. "Conveying Correspondence: Early Modern Letter Bearers, Carriers, and Posts." 
Cultures of Correspondence in Early Modern Britain. Ed. James Daybell and Andrew Gordon.

Philadelphia: University of Pennsylvania Press, 2016. 48-65.

Brown, Cedric C. Friendship and its Discourses in the Seventeenth Century. Oxford: Oxford University Press, 2016.

--- "Presence, obligation and memory in John Donne's texts for the Countess of Bedford." Renaissance Studies 22.1 (February 2008): 63-85.

Colclough, David. "Donne, John (1572-1631)." Oxford Dictionary of National Biography. Ed. H. C. G. Matthew and Brian Harrison. Oxford: OUP, 2004. Online ed. Ed. David Cannadine. May 2011. Web. 8 August 2017.

Daybell, James. The material letter in early modern England: Manuscript letters and the culture and practices of letter-writing, 1512-1635. Houndmills and New York: Palgrave Macmillan, 2012.

DiGangi, Mario. Sexual Types: Embodiment, Agency, and the Dramatic Character from Shakespeare to Shirley. Philadelphia: University of Pennsylvania Press, 2011.

Donne, John. John Donne: The Divine Poems. Ed. Helen Gardner. 2nd Ed. Oxford: Oxford University Press, 1978.

---. Letters to severall persons of honour. London, 1651.

---. The Complete Poems of John Donne. Ed. Robin Robbins. Abingdon: Routledge, 2013.

---. The Poems of John Donne. 2 vols. Ed. Herbert J.C. Grierson. Oxford: Oxford University Press, 1912.

---. The Satires, Epigrams, and Verse Epistles. Ed. Wesley Milgate. Oxford: Oxford University Press, 1967.

Edelman, Lee. No Future: Queer Theory and the Death Drive. Durham, NC: Duke University Press, 2004. Finucci, Valeria. "Maternal Imagination and Monstrous Birth: Tasso's Gerusalemme liberata." Generation 
and Degeneration: Tropes of Reproduction in Literature and History from Antiquity through Early Modern Europe. Ed. Valeria Finucci and Kevin Brownlee. Durham and London: Duke University Press, 2001. 41-77.

“Fulfill, v.” Oxford English Dictionary Online. June 2017. Web. 8 August 2017.

Gardner, Helen. John Donne's holograph of 'A Letter to the Lady Carey and Mrs Essex Riche'. London: Scolar Mansell, 1972.

Johnson, Barbara. "Animation, Apostrophe, and Abortion." Diacritics 16.1 (Spring, 1986): 28-47.

Klawitter, George. The Enigmatic Narrator: The Voicing of Same-Sex Love in the Poetry of John Donne. New York: Peter Lang, 1994.

Larson, Deborah Aldrich. John Donne and Twentieth-Century Criticism. London and Toronto: Associated University Presses, 1989.

“Lusty, adj.” Oxford English Dictionary Online. June 2017. Web. 8 August 2017.

Marotti, Arthur. John Donne, Coterie Poet. Madison: University of Wisconsin Press, 1986.

Masten, Jeffrey. Queer Philologies: Sex, Language and Affect in Shakespeare's Time. Philadelphia: University of Pennsylvania Press, 2016.

---. Textual Intercourse: Collaboration, authorship, and sexualities in Renaissance drama. Cambridge: Cambridge University Press, 1997.

Maurer, Margaret. “John Donne’s Verse Letters.” Modern Language Quarterly 37 (1976): 234-59. Maus, Katherine Eisaman. "A womb of his own: male Renaissance poets in the female body." Sexuality and Gender in Early Modern Europe: Institutions, texts, images. Ed. James Grantham Turner. Cambridge: Cambridge University Press, 1993. 266-88.

May, Steven W. "Donne and Egerton." Oxford Handbook of John Donne. Ed. Jeanne Shami, Dennis Flynn, and M. Thomas Hester. Oxford: Oxford University Press, 2011. 447-59. 
Meakin, H.L. John Donne's Articulations of the Feminine. Oxford: Oxford University Press, 1998.

Meres, Francis. Palladis tamia. London, 1598.

North, Dudley, Third Baron. A Forest of Varieties. London, 1645.

Osborne, Dorothy. Dorotby Osborne: Letters to Sir William Temple, 1652-1654. Ed. Kenneth Parker. Aldershot and Burlington: Ashgate, 2002.

Patterson, Annabel. "Misinterpretable Donne: the testimony of the letters." John Donne Journal 1 (1982): 39-53.

“Queer, adj.1.” Oxford English Dictionary Online. June 2017. Web. 8 August 2017.

Rambuss, Richard. Closet Devotions. Durham and London: Duke University Press, 1998.

Saunders, Ben. Desiring Donne: Poetry, Sexuality, Interpretation. Cambridge, MA and London: Harvard University Press, 2006.

Schneider, Gary. The culture of epistolarity: vernacular letters and letter writing in early modern England, 1500 1700. Newark: University of Delaware Press, 2005.

Sedgwick, Eve Kosofsky. Between Men: English Literature and Male Homosocial Desire. New York: Columbia University Press, 1985.

Shakespeare, William. Shake-speares sonnets. London, 1609.

Shannon, Laurie. “Lear's Queer Cosmos.” Shakesqueer. Ed. Medhavi Menon. Durham and London: Duke University Press, 2011. 171-78.

---. Sovereign Amitie: Figures of Friendship in Shakespearean Contexts. Chicago and London: University of Chicago Press, 2002.

Sidney, Sir Philip. The Poems of Sir Philip Sidney. Ed. William A. Ringler. Oxford: Oxford University Press, 1962. 
Smith, Bruce. Homosexual Desire in Shakespeare's England: A Cultural Poetics. Chicago and London: University of Chicago Press, 1991.

Smith, Daniel Starza. John Donne and the Conway Papers. Oxford: Oxford University Press, 2014.

Stein, Arnold. “Donne’s Prosody.” PMLA 59.2 (Jun., 1944): 373-97.

Stevens, Forrest Tyler. 'Erasmus's 'Tigress': The Language of Friendship, Pleasure, and the Renaissance Letter.” Queering the Renaissance. Ed. Jonathan Goldberg. Durham: Duke University Press, 1994. 124-40.

Stewart, Alan. "Shakespeare and the Carriers." Shakespeare Quarterly 58.4 (Winter, 2007): 431-64.

“till, v.1.” Oxford English Dictionary Online. June 2017. Web. 8 August 2017.

Tosh, Will. Male Friendship and Testimonies of Love in Shakespeare's England. London: Palgrave Macmillan, 2016.

“† tottered, adj.” Oxford English Dictionary Online. June 2017. Web. 8 August 2017.

Traub, Valerie. The Renaissance of Lesbianism in Early Modern England. Cambridge: Cambridge University Press, 2002.

“Westmoreland MS (NY3).” DigitalDonne: The Online Variorum. Department of English, Texas A\&M University. Web. 8 August 2017. 